\title{
Measuring Neighborhood Quality of Life: Placed-Based Sustainability Indicators in Freiburg, Germany
}

\author{
Craig A. Talmage ${ }^{1 \oplus}$, Bjoern Hagen ${ }^{2}$, David Pijawka ${ }^{3, *}$ and Cara Nassar ${ }^{4}$ \\ 1 Entrepreneurial Studies Hobart \& William Smith Colleges, Geneva, NY 14456, USA; Talmage@hws.edu \\ 2 School of Sustainability, Arizona State University, Tempe, AZ 85281, USA; bjoern.hagen@asu.edu \\ 3 School of Geographical Sciences and Urban Planning and School of Sustainability, Arizona State University, \\ Tempe, AZ 85281, USA \\ 4 Valley Metro RPTA, 101 North 1st Ave, Phoenix, AZ 85003, USA; cnassar@asu.edu \\ * Correspondence: pijawka@asu.edu; Tel.: +1-480-727-7319
}

Received: 17 September 2018; Accepted: 26 October 2018; Published: 29 October 2018

\begin{abstract}
There has been a recent upswing of academic interest in the social dimensions of sustainable cities, especially the dynamics of Quality of Life (QoL), Environmental Equity, Ecosystem Services, Eco-Friendliness, Public Engagement, and Well-Being and Happiness Indicators. These factors are only now being evaluated as critical aspects of sustainable place-making and community development. This paper explores the social dimensions of neighborhood development in what some believe to be one of the most sustainable cities-Freiberg, Germany. We look at two neighborhoods that were specifically designed and built with sustainability principles and practices at their core. The authors surveyed residents of these neighborhoods to measure their levels of well-being, satisfaction with place, and other important QoL factors. Quantitative data was ascertained from residents using a survey questionnaire. The results show a high correlation between QoL factors as a function of place-making and sustainability practice.
\end{abstract}

Keywords: place-making; place attachment; sense of place; sustainable community development

\section{Introduction}

Growing academic interest in the social dimensions of sustainable cities has broadened the field of urban science to become more interdisciplinary. Researchers are looking to fields such as community development and Quality of Life (QoL) for social indicators related to sustainable development. Broad concepts including sense of place, place-making, and place-based indicators common in community development, neighborhood development, and planning literature are now found in sustainable city work. These social indicators have the unique capacity to help city designers, developers, managers, and officials understand the relationships between urban residents and their built and natural environments as well as social and community environments [1].

This study undertakes an assessment of these broad place-based concepts and their connections with community satisfaction and QoL. It takes place in two planned sustainable neighborhoods in Freiburg, Germany-Rieselfeld and Vauban. These locations were chosen due to Freiburg's reputation as one of the world's most sustainable cities and the city's deliberate emphasis on sustainability and resiliency in developing these two neighborhoods. The study's goals are to (a) help increase understanding regarding the importance of place-based indicators in measuring the success of sustainable development at the local urban level, and (b) highlight important connections between indicators of QoL, sustainability, resiliency, and place-based indicators. 
The work on sustainability and resiliency presented in this paper is based on the definitions by Meerow et al. [2] and the World Commission on the Environment and Development [3]. Meerow et al. defines resiliency in an urban context as "the ability of an urban system-and all its constituent socio-ecological and socio-technical networks across temporal and spatial scales-to maintain or rapidly return to desired functions in the face of a disturbance, to adapt, to change, and to quickly transform systems that limit current or future adaptive capacity." The World Commission on the Environment and Development defines sustainability from a development perspective as "development that meets the needs of the present without compromising the ability of future generations to meet their own needs." A detailed discussion of placed-based indicators is provided in Section 1.1, but it is important to understand that this study focuses primarily on the social dimension of sustainable neighborhood design and thus examines only place-based indicators with social implications.

The manuscript begins by discussing place-based indicators and characteristics of sustainably planned neighborhoods. This leads into the introduction of the two sustainably planned neighborhoods surveyed via questionnaire regarding QoL, placed-based indicators, and sustainability. The factors measured, analyzed, and discussed in this study include factors (1) explaining the decision of current residents of Rieselfeld and Vauban to move there, (2) environmental behavior and attitudes among the residents, (3) social engagement within the two neighborhoods, (4) housing and neighborhood satisfaction, (5) and neighborhood expectations. A more detailed description of the factors as well as the way they were measured is provided in Section 2.2 of this paper. The study methods and findings in Section 3 showcase correlations between these factors. Section 4 provides the context for interpreting the study findings including limitations and directions for future research.

\subsection{Why Look at Place-Based Indicators?}

Place-based indicators are not new to sustainable community development and are very diverse [4-7]. These indicators often focus on individual and community perceptions of their environments as well as their affect or feelings towards those environments. "Sense of Place", for example, is a social indicator that has been especially connected to sustainable community development. Sense of place generally concerns the meaning individuals place upon a specific location or community [8]. Table 1 outlines previous place-based constructs in addition to measuring sense of place.

Table 1. Sense of Place Conceptualizations.

\begin{tabular}{cc}
\hline Conceptualization & Reference \\
\hline Aesthetics & {$[9]$} \\
Attachment (Emotion and Functional) & {$[8-10]$} \\
Climate & {$[9]$} \\
Culture & {$[9]$} \\
Customs & {$[11]$} \\
Dependence & {$[8,9,12]$} \\
Familiarity & {$[7]$} \\
Identity & {$[8,9,12]$} \\
Nature Bonding & {$[9]$} \\
Privacy & {$[9]$} \\
Sense of Belonging & {$[9,13]$} \\
Social Bonding & {$[9,10,14]$} \\
Social Interaction & {$[9,14-16]$} \\
Spirituality & {$[16]$} \\
\hline
\end{tabular}

The measurement of these place-based constructs has been linked to various measures related to the success of sustainable neighborhoods. For example, the relationship between sustainability efforts and sense of place are likely mutually beneficial where one can be leveraged to increase the other 
and vice versa [6]. Much more research is still needed regarding place-based indicators. For instance, community health and well-being are not universally connected to place-based indicators across studies [17]. This study adds to the evidence regarding the link between sense of place and other place-based concepts regarding the social aspects of sustainable neighborhoods. It is important to note that it focuses primarily on the social dimension of sustainable neighborhood design by examining only place-based indicators with social implications.

Researchers often include safety perception indicators in questionnaires and methods regarding sense of place [18,19]. These types of place-based indicators help us understand the various vulnerabilities of and risks to neighborhoods [20,21]. They may also help us understand community resiliency [20]. Sense of place is generally a strength-based indicator coupling asset-based or capacity building efforts as well [22]. Pstross, Talmage, and Knopf [23] note the importance of including both assets and vulnerabilities in community development assessments, so the voices of the community can be best shared.

Values are also influential on place-based indicators. While measurement of environmental values has had some traction in the literature $[8,24]$ especially in the field of ecosystem services, there remains great room for their inclusion in measures and perceptions of sustainable neighborhoods [25,26]. Place-based social indicators may help reinforce or build values for the local community and environment [27]. Furthermore, community values can be mapped into different typologies and used to inform environmental or sustainable development efforts [28]. This study looks at the relationships between community and environmental values in its assessment of place-based indicators and the perceptions of community satisfaction and QoL.

Indicators research concerning well-being can take macro and micro approaches. Macro approaches look at aggregate figures or rates and may compare different communities to those figures or rates. Micro-indicators look at well-being within communities and may compare individuals or groups within those communities. Macro-indicators of sustainable development in the U.S. associate with macro-happiness indicators [29]; however, more studies using micro-indicators are needed to understand which specific social aspects of sustainable neighborhoods are most important to their residents. Social indicators, especially micro-social indicators, have been linked to community satisfaction, which can enrich community development and lead to involvement and engagement [30]. Similarly, Badham [31] calls for place-based indicators to be democratized, which requires more micro-level approaches. Meta-analyses and cross-community and -country analyses will also help inform future work regarding community well-being. Community indicators that include both social and place-based have demonstrated merits in work across studies to assess community well-being [32]. This study adds to this body of work by specifically looking at intentionally planned sustainable neighborhoods.

\subsection{Characteristics of Sustainably Planned Neighborhoods}

Ongoing rapid rural to urban migration is transforming natural landscapes and ecosystems into manmade urban environments, creating unique and complex social, economic, and environmental challenges. Today, more than $50 \%$ of the world's population lives in urban areas. This trend is continuing with projections suggesting that the percentage will increase to $68 \%$ by 2050 [33]. This will be coupled with significant increases in "ecological footprints" associated with urbanization. Increasing changes in land uses and urbanization emphasizes the need for sustainable neighborhood development, including at the neighborhood scale. A vast amount of literature on sustainable development already exists [34-37] and is, therefore, only briefly discussed in the following paragraph. Rather, the paper's focus is on the social dimension of neighborhood development.

The increasing number and growth of urban settlements provides an opportunity to address environmental and social challenges through comprehensive sustainable neighborhood policies and planning strategies. Moreover, the growth in the number and size of megacities, or those cities with populations over 10 million, requires a greater emphasis on planning cities and their 
neighborhoods based on social well-being and QoL factors as key factors in sustainable development efforts. The research presented here addresses this need.

Existing literature emphasizes five dimensions of sustainable development that are key to successfully creating sustainability in urban communities or neighborhoods [13,38]: (1) economic sustainability, (2) social sustainability, (3) ecological sustainability, (4) sustainable spatial development, and (5) cultural continuity. As a result, different approaches have emerged that promote the application of these dimensions to sustainable urban neighborhoods. Research has demonstrated the efforts of neighborhoods excelling in various social aspects of sustainable neighborhood planning [39]. For example, Li el al. [40] and Webster et al. [41] discuss Beijing's approach to urban sustainability through ecosystem development; Joubert [42] focuses on cultural dimensions; Jones et al. [43] addresses the importance of economic stability; Hopwood et al. [44] highlights the human dimension; and Galster et al. [45] centers around identifying thresholds and barriers for achieving sustainable neighborhoods.

Like sustainable development, the social dimension of sustainable neighborhood planning is a complex and interdisciplinary concept with various explanatory factors and multiple theoretical thrusts [1]. While there is wide acceptance of the importance of the role and importance of the social factors, but its goals and how to reach these goals through planning and policy are still unclear [46,47]. Outside of social and environmental justice, the social area of sustainability has not been fully addressed, especially at the neighborhood level [48].

The paper's goal is to investigate how the social factors work in achieving neighborhood sustainability and which ones are critical to achieving positive results in amenities. We need to gain an understanding on how to quantify the social indicators and to plan communities using social factors $[46,47,49,50]$.

Specific services and facilities at the neighborhood scale, which are often directly related to urban form, impact social well-being and happiness. There have been several studies recently that have focused on the services and facilities at the neighborhood scale that have attempted to include social well-being, happiness, and QoL. Winter and Farthing [51] identified eight indicators leading to neighborhood satisfaction QoL, and social participation. Most of these were facilities such as schools, supermarkets, and other amenities. Other studies point to access to health facilities, cafés, and community centers [52-54]. Table 2 shows the findings from the literature for both the physical and non-physical/social indicators critical in developing sustainable neighborhoods $[1,55]$. Non-physical indicators included cultural traditions, cohesion, social justice, participation, community, and residential stability, among others.

Table 2. Contributing Factors to Urban Social Sustainability.

\begin{tabular}{|c|c|}
\hline Non-Physical Factors & Predominantly Physical Factors \\
\hline $\begin{array}{l}\text { - } \\
\text { - } \\
\text { Social justice, -inclusion, -capital, -order, -cohesion, } \\
\text {-networks, -interaction } \\
\text { - } \quad \text { Participation, local democracy, and active community organization } \\
\text { - } \quad \text { Comm, quality of life, and well-being } \\
\text { and belonging } \\
\text { - Safety, employment, residential stability, mixed tenure, fair } \\
\text { distribution of income }\end{array}$ & $\begin{array}{ll}\text { - } & \text { Urbanity } \\
\text { - } & \text { Attractive public realm } \\
\text { - } & \text { Decent housing } \\
\text { - } & \text { Accessibility } \\
\text { - } & \text { Sustainable urban design } \\
\text { - } & \text { Neighborhood } \\
\text { - } & \text { Walkability }\end{array}$ \\
\hline
\end{tabular}

Notes: Adapted from Dempsey et al. [1], Ghahramanpuri et al. [56].

\subsection{The Case of Freiburg, Germany and Two Sustainably Planned Neighborhoods}

This paper looks at social and place-based indicators of neighborhood development in what some believe to be one of the most sustainable cities-Freiberg, Germany. In this study, we look at two neighborhoods specifically designed and built with sustainability principles and practice at their 
core. This article does not go into the details of Freiberg's history and design processes due to the vast amount of literature already available [26,56-59]. Rather, we provide basic information about the city and the two neighborhoods, Rieselfeld and Vauban, which are the focus of this paper. Important planning policies of the city and differences between the two neighborhoods are discussed in more detail as part of explaining results of some of the statistical analyses. Figure 1 shows the locations of these neighborhoods.

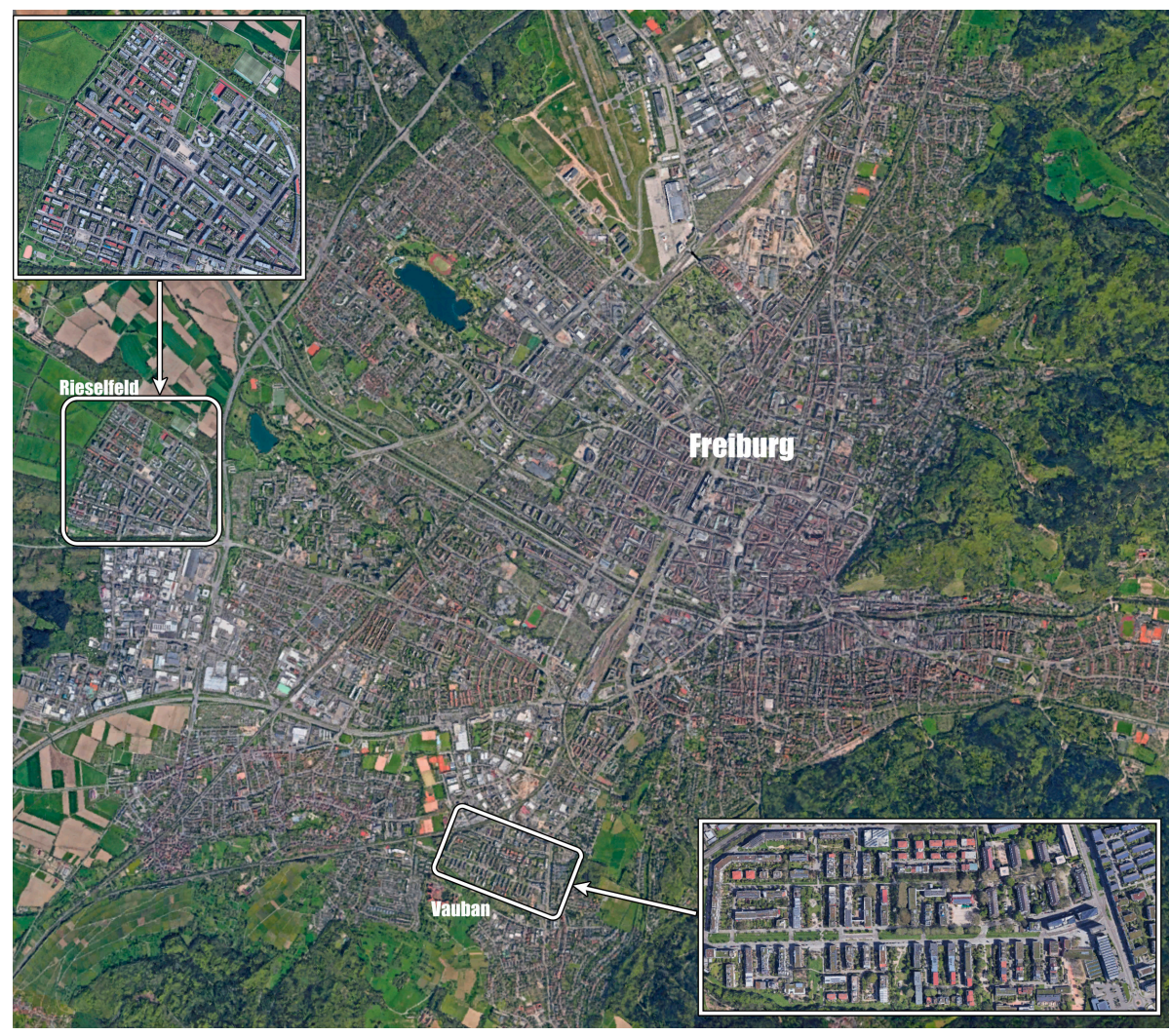

Figure 1. Map Showing Locations of Freiburg Neighborhoods (from Google Maps).

Located at the foothills of the Black Forest in the Southwest corner of Germany and near the Swiss and French borders, the City of Freiburg has a population of approximately 220,000 people. Freiberg became known for its green infrastructure, public transportation, solar applications, and significant public participation. Today, the city supports eco-tourism, universities, and research. For example, The Albert Ludwig University in Freiburg is one of the oldest universities in Germany and provides a significant share of employment opportunities.

Fostered by the large academic community, the green movement was strong in the city as early as the 1970s. This resulted in a successful protest against the construction of a nuclear power plant close to the city [60], with the city's leadership committing to sustainable development as policy [58,61]. By the 1980s, equity considerations and sustainable development objectives were integrated with social and community participation goals. Support for public participation and long-term planning policies supporting sustainable growth and strategies for environmentally friendly investments paved the way for the development of the two neighborhoods when housing shortages became apparent.

Other studies also point to this period as a milestone as Freiburg's history. The political landscape was certainly impacted, as city officials committed to long-term sustainability, including an increase in the renewable energy portfolio [59,61]. According to former mayor Dieter Salomon (2002-2018), the city's long-term strategic approach included proactive government willing to embrace forward thinking policies, strong public participation, and support for environmentally friendly businesses and policies [62]. 
These developments stand out in the public discussion and academic literature on Freiburg's efforts to become more sustainable as they are considered "eco-neighborhoods" [63]. Their development has entailed different interpretations and ideologies of what a sustainable community is as well as size and planning approaches. Vauban, an infill development located on a former French military base, was designed as a family-friendly community for 5500 residents. Its development phase began in 1994 with construction beginning in 1998. The neighborhood was fully developed by $2010[64,65]$. Rieselfeld was built on the outskirts of Freiburg as a greenfield development for up to 12,000 residents. Construction began in 1995 [66]. The first resident moved to Rieselfeld in 1996 and the neighborhood was fully developed by 2018 [26].

Corresponding to the environmental movement, a housing-related social movement developed as well in the early 1980s aimed at countering a developing housing crisis that was pricing younger residents out of the market. This shortage led to increased cost of living within the city and rapid suburbanization. As a result, policy makers explored social equity opportunities such as more affordable and equitable housing during their planning and construction of Rieselfeld and Vauban. In both cases, the development process addressed these issues, not only through the integration of sustainable design and ecological concepts, but also by engagement that acknowledged the need for community-based social infrastructure and programs. Today, both neighborhoods are held in high esteem for their holistic social-based sustainability planning. The research presented in this publication evaluates the social responses and characteristics of those living in these communities.

\section{Materials and Methods}

\subsection{Questionnaire Development and Distribution}

This study used a questionnaire survey method. The questionnaire consisted of 27 questions and was administered in January 2017. A total of 204 household surveys were collected from the two neighborhoods, 107 in Vauban and 97 in Rieselfeld. Table 3 illustrates the characteristics of the two neighborhood survey samples. This represents 3.4\% (4.2\% in Vauban and 2.9\% in Rieselfeld) of the total households in the neighborhoods and the sample represents $\pm 6.74 \%$ at the $95 \%$ confidence level. A researcher went door to door collecting responses over several weeks. As a result, there was a $100 \%$ response rate.

Table 3. Characteristics of Surveyed Population.

\begin{tabular}{|c|c|c|c|c|c|c|c|}
\hline Gender & Female & Male & N/A * & & & & \\
\hline Rieselfeld & $51.6 \%$ & $44.3 \%$ & $4.1 \%$ & & & & \\
\hline Vauban & $53.4 \%$ & $44.7 \%$ & $1.9 \%$ & & & & \\
\hline Age Groups & 18 to 24 & 25 to 34 & 35 to 44 & 45 to 54 & 55 to 64 & $65+$ & N/A * \\
\hline Rieselfeld & $8.2 \%$ & $4.1 \%$ & $10.3 \%$ & $50.5 \%$ & $19.6 \%$ & $5.2 \%$ & $2.1 \%$ \\
\hline Vauban & $14.5 \%$ & $1.9 \%$ & $5.8 \%$ & $43.7 \%$ & $21.4 \%$ & $7.8 \%$ & $4.6 \%$ \\
\hline Children per household & 0 & 1 & 2 & 3 & $4+$ & Mean & \\
\hline Rieselfeld & $33.0 \%$ & $24.7 \%$ & $27.8 \%$ & $11.3 \%$ & $3.1 \%$ & 1.3 & \\
\hline Vauban & $46.6 \%$ & $20.4 \%$ & $23.3 \%$ & $8.7 \%$ & $1.0 \%$ & 1.0 & \\
\hline Time living in ... & $<1$ year & $\begin{array}{c}1-3 \\
\text { years }\end{array}$ & $\begin{array}{c}4-6 \\
\text { years }\end{array}$ & $\begin{array}{c}7-9 \\
\text { years }\end{array}$ & $\begin{array}{c}10+ \\
\text { years }\end{array}$ & & \\
\hline Rieselfeld & $5.2 \%$ & $5.2 \%$ & $5.2 \%$ & $15.5 \%$ & $69.1 \%$ & & \\
\hline Vauban & $4.9 \%$ & $9.7 \%$ & $7.8 \%$ & $5.8 \%$ & $71.8 \%$ & & \\
\hline Living Situation & Rent & Own & N/A & & & & \\
\hline Rieselfeld & $12.4 \%$ & $85.5 \%$ & $3.1 \%$ & & & & \\
\hline Vauban & $24.3 \%$ & $68.9 \%$ & $7.0 \%$ & & & & \\
\hline
\end{tabular}


The surveys were collected randomly over a two-week period. The household respondents who were at least 18 years of age. The survey was translated into German for those households that had difficulties with English. There were no issues related to the English to German translation.

\subsection{Measures}

Individual place-based values regarding the decision to live in the community were assessed using a seven-point Likert scale ranging from (1) not important at all to (4) moderately important to (7) would not have relocated without it. Ten value items were presented and measured: (1) safety; (2) peace and quiet; (3) affordability of housing; (4) quality of schools; (5) high sense of community; (6) easy to walk places; (7) energy efficiency of household; (8) public amenities (i.e., sport fields, community space); (9) environmental-friendly design; and (10) QoL.

Residents were also asked seven questions specific to climate change adaptation and environmental sustainability as it has been tied to self-identity and sense of place (Herrick, 2018). These were assessed using a five-point Likert scale ranging from (1) strongly disagree to (5) strongly agree. The statements are as follows:

- I believe that climate change is affecting the environment

- I make a considerable effort to recycle things that I use

- I don't really pay attention to the amount of energy used in my household

- I have made considerable efforts to change my habits in the past five years because of environmental issues

- If available, I would be willing to use a public transit system from my home to work

- Our household tries to purchase energy-efficient appliances

- Climate Change is something humans do not influence

Neighborhood social engagement and characteristics were assessed using seven-point Likert scales with three anchors. Residents were asked if they knew their neighbors on their street (1-none of my neighbors; 4-half of the neighbors; and, 7-all of my neighbors). They were asked if they felt they could influence decisions affecting their neighborhood (1-no influence; 4 -some influence; and, 7-I am most influential). They were also asked if family members were involved in neighborhood organizations (1-no involvement; 4-some involvement; and, 7-very involved). Finally, they were asked if living in the neighborhood today was what they expected before moving there (1-absolutely not; 4 -somewhat surprised; and, 7-No surprises).

Housing satisfaction was assessed using a five-point Likert scale ranging from (1) very dissatisfied to (5) very satisfied. Residents were asked: How satisfied are you with your current housing situation? Housing satisfaction was not considered among the dependent measures in this study, because it concerned the individuals' property and not perceptions of the community.

Three forms of satisfaction were examined. "Neighborhood satisfaction" was assessed using a five-point Likert scale ranging from (1) very dissatisfied to (5) very satisfied. Residents were asked: Overall, how satisfied are you living in this neighborhood? "Decision satisfaction" was assessed with the following: I am very satisfied with my decision moving into this neighborhood. Assessment used a seven-point Likert scale with three anchors: (1) it was a mistake; (4) somewhat satisfied; and, (7) could not be happier. "Expectations Satisfaction" was assessed with the following: On a scale from 1 to 7 , with 1 being (did not meet my expectations at all) and 7 being (exceeds my expectation), to what degree does the experience living in this neighborhood meet the expectations you had before moving here?

Demographic characteristics were collected for comparisons and to gain an understanding of the sample's background. These included participants' gender and age as well as household characteristics, e.g., the number of children in the home, home ownership/renter status, neighborhood tenure, and the type of community they had previously lived in (e.g., city, rural, or suburb). 


\subsection{Sample Background}

The study engaged a total of 200 participants, which were split relatively evenly between the two neighborhoods (51.5\% Vauban, $48.5 \%$ Rieselfeld). The study sample was also nearly evenly divided regarding gender ( $52.5 \%$ women, $44.5 \%$ men). Vauban had 55 women respond and 46 men respond. Rieselfeld had 50 women respond and 43 men respond. 6 participants did not indicate their gender.

The median age of the study sample was 45 to 54 years of age constituting $47.0 \%$ of the study sample. The second largest age group was individuals between ages 55 and 64 (20.5\%). Younger adults (18-35) represented $14.5 \%$ and elderly adults (over 65) $6.5 \%$ of the study sample. Most individuals had between 1 to 3 children less than 18 years of age living at home (58.0\%), but a large proportion of individuals $(40.0 \%)$ had no children less than 18 years of age living with them.

The majority of those surveyed $(76.5 \%)$ owned their homes with $18.5 \%$ of households renting their homes. Vauban had 71 homeowners and 25 renters complete the survey. Rieselfeld had 72 homeowners and 12 renters complete the survey. Five percent (5.0\%) of surveyed individuals did not answer this question. Most residents (70.5\%) had lived in the neighborhood for 10 or more years. Those who had moved to the area tended to generally come to the neighborhood from an urban area (73.9\%) rather than a rural or suburban area.

\subsection{Data Analysis}

For comparison analyses, $t$-tests and chi-square tests were implemented depending on the type of scale used and data acquired. Specifically, differences between the two neighborhoods were investigated prior to any regression analyses on the social factors. For regression analyses, this study used stepwise linear regression (entering variables at $\alpha=0.05$ ) to analyze the survey's independent and dependent variable relationships. This procedure is appropriate for exploratory data analysis as noted by others (e.g., Talmage et al., [67]) as it helps reduce collinearity, which exploratory research models should prevent [68]. Arizona State University's Institutional Review Board (IRB) approved the study, the survey instruments, and the translation of the survey to German. The IRB ID is STUDY00005514.

\section{Results}

\subsection{Neighborhood Differences}

Significant differences were observed between Vauban and Rieselfeld across six variables. Findings are organized based on $t$-tests and chi-square tests.

- Rieselfeld residents tended to know their neighbors on their street (Mean $=5.396, \mathrm{SD}=1.714)$ to a significantly greater level $(t[196]=-2.469, p<0.05)$ than Vauban residents (Mean $=4.833$, $\mathrm{SD}=1.490)$.

- Vauban residents tended to mark easily to walk places as important in their decision to move to that neighborhood $($ Mean $=5.544, S D=1.725)$ to a significantly greater level $(t[198]=2.353$, $p<0.05$ ) than Rieselfeld residents (Mean $=4.959$, $\mathrm{SD}=1.791$ ).

- Rieselfeld residents also tended to mark public amenities as important in their relocation decisions (Mean $=5.041, \mathrm{SD}=1.541)$ to a significantly greater level $(t[198]=-3.042, p<0.05)$ than Vauban residents $($ Mean $=4.330, \mathrm{SD}=1.751$ ).

- Rieselfeld residents were significantly more likely to own their homes compared to Vauban residents $\left(\chi^{2}[1]=5.338, \phi=0.168, p<0.05\right)$.

- $\quad 87.2 \%$ of Rieselfeld residents owned their homes compared to $74.0 \%$ of Vauban residents.

- Rieselfeld residents also were significantly more likely drive a car more often than Vauban residents before and after their relocation $\left(\chi^{2}[3]=7.453\right.$, Cramer's $V=0.196, p<0.1 ; \chi^{2}[3]=21.574$, Cramer's $V=0.331, p<0.001$; respectively). The difference in driving a car was more significant and salient after relocation. 


\subsection{Regression Models}

Importantly, the study found seven place-based social indicators were significantly related to the three community satisfaction measures (Figure 2).

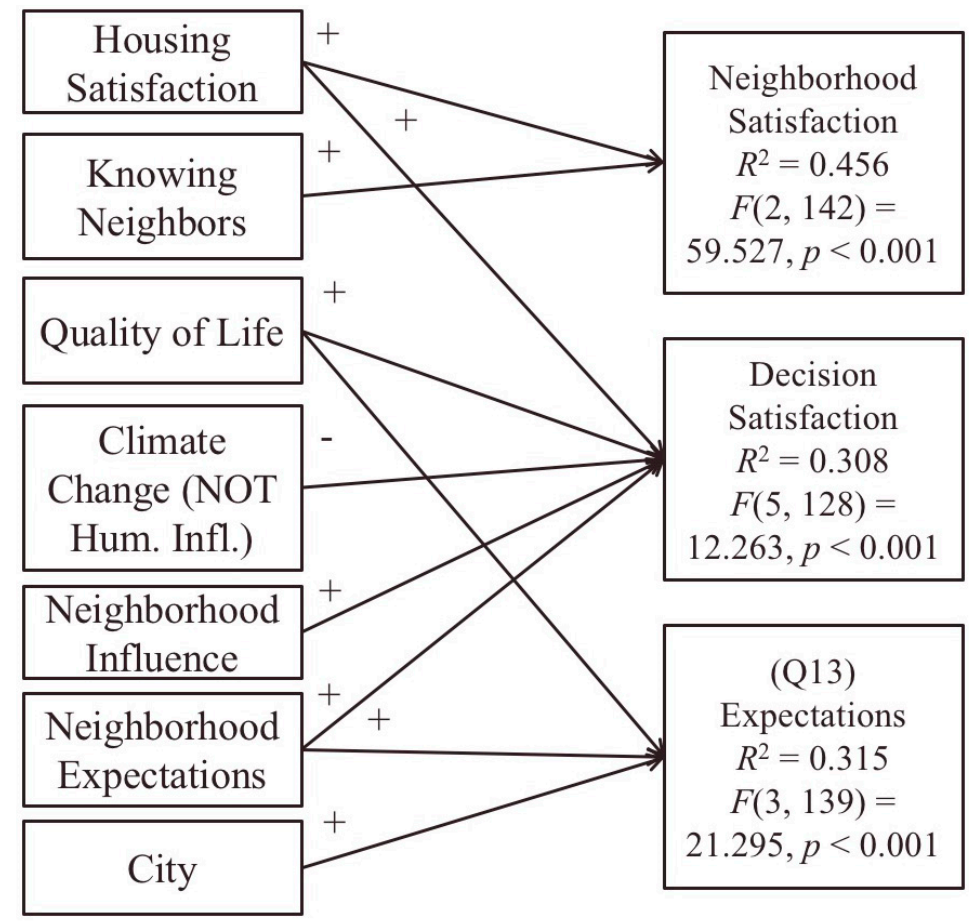

Figure 2. Summary Depiction of Satisfaction Models.

Only two indicators significantly explained $45.6 \%$ of the variance in neighborhood satisfaction $(F[2,142]=59.527, p<0.001)$. Housing satisfaction was the strongest indicator, followed by knowing one's neighbors (Table 4).

Table 4. Neighborhood Satisfaction Regression Coefficients.

\begin{tabular}{ccccccccc}
\hline Neighborhood Satisfaction & B & S.E. & Beta & $\boldsymbol{t}$ & $\boldsymbol{p}$ & Partial & Part & VIF \\
\hline (Constant) & 0.759 & 0.382 & - & 1.985 & $<0.05$ & - & - & - \\
Housing Satisfaction & 0.616 & 0.058 & 0.655 & 10.584 & $<0.001$ & 0.664 & 0.655 & 1.000 \\
Knowing Neighbors & 0.146 & 0.055 & 0.164 & 2.651 & $<0.01$ & 0.217 & 0.164 & 1.000 \\
\hline
\end{tabular}

Five indicators significantly explained $30.8 \%$ of the variance in decision satisfaction (how satisfied people were with their decision to move into the neighborhood) $(F[5,128]=12.263, p<0.001)$. Again, housing satisfaction was the most salient indicator. The second most salient indicator was the importance of QoL to relocation. Neighborhood characteristics, such as expectations and feelings that one has influence over neighborhood decisions, also associated with decision satisfaction. A negative relationship was observed between beliefs that climate change is not influenced by humans and decision satisfaction (Table 5).

Table 5. Decision Satisfaction Regression Coefficients.

\begin{tabular}{ccccccccccc}
\hline Decision Satisfaction & B & S.E. & Beta & $t$ & & Partial & Part & VIF \\
\hline (Constant) & 1.226 & 0.811 & - & 1.511 & ns & - & - & - \\
Housing Satisfaction & 0.342 & 0.070 & 0.349 & 4.890 & $<0.001$ & 0.384 & 0.346 & 1.014 \\
Quality of Life & 0.353 & 0.102 & 0.251 & 3.482 & $<0.01$ & 0.284 & 0.247 & 1.037 \\
Neighborhood Influence & 0.206 & 0.070 & 0.209 & 2.930 & $<0.01$ & 0.242 & 0.208 & 1.015 \\
Climate Change (NOT Human Influenced) & -0.371 & 0.125 & -0.211 & -2.972 & $<0.01$ & -0.245 & -0.211 & 1.008 \\
Neighborhood Expectations & 0.173 & 0.079 & 0.157 & 2.177 & $<0.05$ & 0.182 & 0.154 & 1.034 \\
\hline
\end{tabular}


Three indicators significantly explained $31.5 \%$ of the variance in expectations satisfaction $(F[3,139]=21.295, p<0.001)$. The most salient was the importance of QoL to relocation. Not surprisingly, neighborhood expectations were associated with expectations satisfaction. Additionally, there were neighborhood differences observed in the regression model, with Rieselfeld residents having their expectations satisfied more when compared to Vauban residents (Table 6).

Table 6. Expectations Satisfaction Regression Coefficients.

\begin{tabular}{ccccccccc}
\hline Expectations Satisfaction & B & S.E. & Beta & $t$ & $p$ & Partial & Part & VIF \\
\hline (Constant) & 1.953 & 0.499 & - & 3.914 & $<0.001$ & - & - & - \\
Quality of Life & 0.491 & 0.068 & 0.516 & 7.216 & $<0.001$ & 0.522 & 0.507 & 1.036 \\
Neighborhood & 0.329 & 0.138 & 0.168 & 2.377 & $<0.05$ & 0.198 & 0.167 & 1.018 \\
Neighborhood Expectations $^{*}$ & 0.109 & 0.053 & 0.146 & 2.054 & $<0.05$ & 0.172 & 0.144 & 1.020 \\
\hline
\end{tabular}

* Rieselfeld residents appear to have their expectations satisfied more compared to Vauban.

Further investigation was conducted to unearth the place-based indicators associated with the importance of QoL to relocation. Four indicators significantly explained $43.2 \%$ of the variance in QoL importance $(F[4,162]=32.579, p<0.001)$. The strongest influential indicator was the importance of peace and quiet to relocation, followed closely by environmental-friendly design. The importance of a high sense of community was also associated with QoL. Finally, individuals who rented homes in the neighborhoods appeared to find QoL less important to relocation decisions (Table 7).

Table 7. Quality of Life Regression Coefficients.

\begin{tabular}{ccccccccc}
\hline Quality of Life & B & S.E. & Beta & $\boldsymbol{t}$ & $\boldsymbol{p}$ & Partial & Part & VIF \\
\hline (Constant) & 3.107 & 0.331 & - & 9.390 & $<0.001$ & - & - & - \\
Peace and Quiet & 0.266 & 0.046 & 0.369 & 5.850 & $<0.001$ & 0.418 & 0.342 & 1.160 \\
Environmental-Friendly Design & 0.249 & 0.048 & 0.339 & 5.163 & $<0.001$ & 0.376 & 0.302 & 1.263 \\
High Sense of Community & 0.122 & 0.044 & 0.175 & 2.750 & $<0.01$ & 0.211 & 0.161 & 1.184 \\
Rent & -0.361 & 0.161 & -0.133 & -2.238 & $<0.05$ & -0.173 & -0.131 & 1.028 \\
\hline
\end{tabular}

\section{Discussion}

\subsection{Explaining Neighborhood Differences and Similarities}

Rieselfeld and Vauban have many things is common, but also several significant differences that are worth noting and can help to understand neighborhood differences discussed earlier. Rieselfeld represents a planned neighborhood with long-term strategies to develop new affordable housing to meet the needs of the younger generation who could not afford to remain in or move to the City of Freiburg. While Rieselfeld demonstrates a top-down policy approach based on social equity, Vauban planners used a bottom-up grassroots planning approach when land became available. Rieselfeld can also be characterized as a relatively self-contained new urban district compared to the smaller Vauban neighborhood.

Despite these differences, both developments focused on limiting the involvement of investors and keeping prices down as much as possible. In the early stages of its planning and construction process, roughly $20 \%$ of the apartments were planned as affordable housing units. Due to significant housing shortages, however, home values increased rapidly prohibiting the city from reaching this goal. The city government managed the development process based on sustainable management principles, and therefore, was able to encourage strong public involvement [69]. This helped to meet some of the city's social equity goals undermined by market-driven housing costs. For instance, both building sites provided land for cooperative building developments based on collaborative "bottom-up" designs.

With the help of assigned architects and city oversight, this collaborative approach also included strategies for finance and design of housing units to ensure household needs were met. From the perspective of sustainable neighborhood development and engagement, this approach is very beneficial 
in terms of allowing direct public participation involvement. This included establishing social connections and community bonding from the start. Moreover, residents saw significant cost saving as well as the planning move away from the developer-driven model of design and construction [70]. Measured factors such as sense of community, community organization, accessibility, and sustainable urban design (i.e., energy-efficient building design, car-free zones) stand out in both neighborhoods due to these unique social sustainable development and resiliency approaches.

The sustainable design elements in both neighborhoods have strong similarities, but there are noticeable differences here as well. Based on fundamental design, both neighborhoods are car-free with low internal mobility requirements and high levels of green infrastructure such as natural wastewater discharge systems. Easy access to public transit systems such as bus and light rail are also available. Reducing the use of the private automobile was a focal point in the designs of both communities. Vauban went as far as establishing car-park-free housing that requires purchasing parking at the edges of the development. In Rieselfeld, parking is mostly available only in back alleys and in underground parking structures. The housing, built on superblock designs, was found to support high levels of walkability, social interaction, and shared garden space. These traits were influential in residents' decision to move to the neighborhood, satisfaction with living in the neighborhood, and QoL.

As described earlier in the paper, social engagement and civic organizations were established early as part of the development design. They were critical in nurturing a sense of cohesion and community in the neighborhoods as they matured [71]. This also made both neighborhoods more resilient and less vulnerable to external shocks and threats by building social capacity. These institutions established community connections and a social infrastructure that enhanced the sense of place, place identity, and "belonging". This is demonstrated in the significant neighborhood satisfaction, high level of articulated QoL, and social resiliency. As a result, the data show little outmigration from the neighborhoods and a significant level of stability.

\subsection{Implications for Research and Practice}

Future work on place-based indicators in the context of measuring sustainable neighborhoods should consider the following. First, housing satisfaction was the strongest indicator in this study. There were no observed significant differences regarding housing satisfaction between neighborhoods, gender, age, or renters and owners. This indicates that housing is not valued less by any group, nor is it valued more by any group. Housing satisfaction is also strongly correlated with neighborhood satisfaction levels. As indicated, most housing decisions were based on community engagement and design involvement. This suggests that residents embrace sustainably designed homes, their placement within sustainable neighborhoods, and the ability to engage in the development process.

The QoL factor was also important, based on its place-based indicator strength and influence on decision satisfaction. There are a variety of indicators that form the QoL factor, including peace and quiet, environmental-friendly design, and a high sense of community. Importantly, QoL is not something community members simply came to appreciate but was something they desired or specifically sought out. For example, Rieselfeld and Vauban residents highly value peace and quiet, and environmental-friendly design. They also indicated that a high sense of community and home ownership were important. Thus, it can be elucidated that environmental-friendly housing and neighborhood design must be concordant with residents' QoL needs and desires. Future QoL investigations in sustainable neighborhoods should consider these indicators alongside QoL measurements.

Future research should also consider incorporating psychological social capital factors [72,73] in their place-based indicators work. Influence of neighborhood decisions (also called efficacy), sense of community, and knowing neighbors were significant indicators in this study, but informal and formal participation was not. Future studies should still consider these informal behaviors (also called neighboring) and formal behaviors (also called community/civic participation) in future assessments 
(for more, see Perkins et al. [72]). Other psychological social capital indicators to be assessed may include self-expression and elite-challenging action [73].

Residents' choices and expectations also remained important indicators. Residents appear better off when they own their own homes, live in the neighborhoods they want, and have their prior expectations met or exceeded. While these facets should not be ignored in future research, they are not unusual findings. Like this study, homeownership has been linked to higher social indicators of well-being, but these associations are often weak [73]. Furthermore, it is not a large surprise that expectations were connected to two satisfaction variables in this study. Residents come to neighborhoods with expectations for the physical and relational environments they encounter, and these expectations related to whether they stay in those communities [74-76].

It should be good news that environmental perceptions were important factors for the satisfaction level with living in the neighborhoods. Environmental-friendly design was related to QoL and to decision satisfaction. Efforts to promote eco-awareness may promote community satisfaction among those living in eco-friendly neighborhoods. Nearly all households interviewed indicated that they were satisfied/highly satisfied with their decision to move into the neighborhood, awareness of environmental and ecosystem assets as well as high levels of renewable energy resulted in community satisfaction.

\subsection{Implications for Policy}

This exploratory study does require future research to further corroborate study findings. However, some implications for policy can be suggested.

- Cities and communities looking to attract and retain well-fitting residents to sustainably planned neighborhoods should make sure their materials and mechanisms used to attract those residents speak to residents' expectations and values, such as views on climate change, peace and quiet, and environmental-friendly design.

- Cities and communities looking to promote positive perceptions of their neighborhoods and QoL should also consider the values of their residents and the psychological social capital (e.g., sense of community or knowing neighbors) present among their communities.

- Sustainably planned cities and communities must recognize potential discrepancies in perceived QoL that may be experienced by renters compared to homeowners.

These policy implications will benefit from further evaluation and later revisions as well.

\section{Conclusions}

There has been discussion over the last decade about the meanings that can be ascribed to the social dimensions of sustainability. Often this dimension has been defined and operationalized as "environmental justice or equity", resulting in a plethora of research and concepts exploring these facets of the field. It has not, however, encouraged other issues such as community social needs, interactive elements with environmental quality and ecosystem services as well as economic development or reduction of ecological footprints to be addressed. This paper shows the importance of the development of the social dimensions of sustainability as a critical aspect of sustainable neighborhood development. It leverages the concepts of social well-being, QoL, community satisfaction, social engagement and community involvement, and community resiliency now being researched and discussed in sustainability urban sciences as part of the social impacts of sustainability.

Thus, the authors elucidate and expand the idea of social dimensions in sustainability science. They attempt to first measure these concepts, discuss how they are operationalized, and finally show the relationships between placed-based factors of sustainability and neighborhood satisfaction. The questions on the social dimensions of sustainability ask how planning for sustainability in urban areas requires measures of QoL, satisfaction of neighborhoods, levels of community social engagement, 
and qualitative measures of success by looking at people's perceptions. All these indicators contribute to making a neighborhood more sustainable and resilient.

This paper helps us understand the measurement of QoL in sustainably planned neighborhoods. The study provides insights regarding the importance place-based and sustainability indicators in future measurement efforts. Residents of Rieselfeld and Vauban strongly correlated perceptions of housing (both ownership and eco-friendliness), community engagement in the neighborhood design, and QoL to satisfaction with moving into the community. Thus, we suggest that these variables are key in planning successful sustainable neighborhoods, acknowledging that future research is needed to corroborate these notions.

Author Contributions: Conceptualization, B.H. and D.P.; Data curation, C.N.; Formal analysis, C.A.T.; Funding acquisition, B.H. and D.P.; Investigation, B.H., D.P. and C.N.; Methodology, B.H. and D.P.; Project administration, D.P.; Visualization, C.A.T.; Writing—original draft, C.A.T., B.H. and D.P.; Writing-review and editing, B.H. and D.P.

Funding: Original research was supported by the Arizona State University School of Geographical Sciences and Urban Planning as well as the European and US Regional and Urban Studies (NEURUS) program.

Conflicts of Interest: The authors declare no conflict of interest.

\section{References}

1. Dempsey, N.; Bramley, G.; Power, S.; Brown, C. The Social Dimension of Sustainable Development: Defining Urban Social Sustainability. Sustain. Dev. 2011, 19, 289-300. [CrossRef]

2. Meerow, S.; Newell, J.P.; Stults, M. Defining urban resilience: A review. Landsc. Urban Plan 2016, 147, 38-49. [CrossRef]

3. World Commission on Environment and Development. Our Common Future; Oxford University Press: Oxford, UK, 1987; ISBN 019282080X.

4. Sullivan, L.E.; Schuster, R.M.; Kuehn, D.M.; Doble, C.S.; Morais, D. Building Sustainable Communities Using Sense of Place Indicators in Three Hudson River Valley, NY, Tourism Destinations: An Application of The Limits of Acceptable Change Process. In Proceedings of the 2009 Northeastern Recreation Research Symposium; Gen. Tech. Rep: NRS-P-66; Watts, C.E., Jr., Fisher, C.L., Eds.; U.S. Department of Agriculture, Forest Service, Northern Research Station: Newtown Square, PA, USA, 2010; pp. 173-179.

5. Snider, A.; Hill, J.; Luo, S.; Buerger, B.; Herstine, J. Implications for Place Attachment in Coastal Reserve Management. Ocean Coast. Manag. 2011, 54, 612-620. [CrossRef]

6. Gurney, G.G.; Blythe, J.; Adams, H.; Adger, W.N.; Curnock, M.; Faulkner, L.; James, T.; Marshall, N.A. Redefining Community Based on Place Attachment in A Connected World. Proc. Natl. Acad. Sci. USA 2017, 114, 10077-10082. [CrossRef] [PubMed]

7. Pijawka, D.; Guhathakurta, S.; Sadalla, E.; Collins, K.; Prakash, M.; McAslan, D. Urban Indicators for Border Areas. In Remaking Metropolis: Global Challenges of the Urban Landscape; Cook, E.A., Lara, J.J., Eds.; Routledge: Oxford, UK, 2013; pp. 103-121. ISBN 0415670829.

8. Jorgensen, B.S.; Stedman, R.C. Sense of Place as An Attitude: Lakeshore Owners Attitudes Toward Their Properties. J. Environ. Psychol. 2001, 21, 233-248. [CrossRef]

9. Gokce, D.; Chen, F. Sense of Place in the Changing Process of House Form: Case Studies from Ankara, Turkey. Environ. Plan B Urban Anal. City Sci. 2018, 45, 772-796. [CrossRef]

10. Shamsuddin, S.; Ujang, N. Making Places: The Role of Attachment in Creating the Sense of Place for Traditional Streets in Malaysia. Habitat Int. 2008, 32, 399-409. [CrossRef]

11. Chatterjee, S. Making Children Matter in Slum Transformations: Lessons from India's National Urban Renewal Mission. J. Urban Des. 2015, 20, 479-506. [CrossRef]

12. Vaske, J.J.; Kobrin, K.C. Place Attachment and Environmentally Responsible Behavior. J. Environ. Educ. 2001, 32, 16-21. [CrossRef]

13. Davenport, M.A.; Anderson, D.H. Getting from Sense of Place to Place-Based Management: An Interpretive Investigation of Place Meanings and Perceptions of Landscape Change. Soc. Nat. Resour. 2005, 18, 625-641. [CrossRef]

14. Talen, E. Sense of Community and Neighbourhood Form: An Assessment of the Social Doctrine of New Urbanism. Urban Stud. 1999, 36, 1361-1379. [CrossRef] 
15. Kyle, G.; Chick, G. The Social Construction of a Sense of Place. Leis. Stud. 2007, 29, 209-225. [CrossRef]

16. Keske, C.M.; Hoag, D.; McLeod, D.M.; Bastian, C.T.; Lacy, M.G. Using Mixed Methods Research in Environmental Economics: The Case of Conservation Easements. Int. J. Mix. Methods Appl. Bus. Policy Res. 2011, 1, 16-28.

17. Lovell, S.A.; Gray, A.R.; Boucher, S.E. Place, Health, and Community Attachment: Is Community Capacity Associated with Self-Rated Health at The Individual Level? SSM Popul. Health 2016, 3, 153-161. [CrossRef] [PubMed]

18. de Groot, M. Exploring the Relationship Between Public Environmental Ethics and River Flood Policies in Western Europe. J. Environ. Manag. 2012, 93, 1-9. [CrossRef] [PubMed]

19. Rogerson, R.; Sadler, S.; Wong, C.; Green, A. Planning Sustainable Communities-Skills and Learning to Envision Future Communities: An Introduction. Town Plan. Rev. 2010, 81, 505-522. [CrossRef]

20. Corburn, J. City Planning as Preventive Medicine. Prev. Med. 2015, 77, 48-51. [CrossRef] [PubMed]

21. Harlan, S.L.; Declet-Barreto, J.H.; Stefanov, W.L.; Petitti, D.B. Neighborhood Effects on Heat Deaths: Social and Environmental Predictors of Vulnerability in Maricopa County, Arizona. Environ. Health Perspect. 2013, 121, 197-204. [CrossRef] [PubMed]

22. Tesoriero, F.; Francis, H. Building Supportive Infrastructure to Support Families of Young Children: A Community-Based Approach. Dev. Pract. Child Youth Fam. Work J. 2011, 28, 33-42.

23. Pstross, M.; Talmage, C.A.; Knopf, R.C. A Story About Storytelling: Enhancement of Community Participation Through Catalytic Storytelling. Community Dev. J. 2104, 45, 525-538. [CrossRef]

24. Brandenburg, A.M.; Carroll, M.S. Your Place or Mine?: The Effect of Place Creation on Environmental Values and Landscape Meanings. Soc. Nat. Resour. 1995, 8, 381-398. [CrossRef]

25. Herrick, C.N. Self-Identity and Sense of Place: Some Thoughts Regarding Climate Change Adaptation Policy Formulation. Environ. Value 2018, 27, 81-102. [CrossRef]

26. Hagen, B.; Nassar, C.; Pijawka, K.D. The Social Dimension of Sustainable Neighborhood Design: Comparing Two Neighborhoods in Freiburg, Germany. Urban Plan. 2017, 2, 64-80. [CrossRef]

27. Fink, K.J. The Effect of Place Attachment on Environmental Values in Oklahoma State Park Visitors. Ph.D. Thesis, Oklahoma State University, Stillwater, DC, USA, 1 May 2011.

28. Raymond, C.M.; Bryan, B.A.; MacDonald, D.H.; Cast, A.; Strathearn, S.; Grandgirard, A.; Kalivas, T. Mapping Community Values for Natural Capital and Ecosystem Services. Ecol. Econ. 2009, 68, 1301-1315. [CrossRef]

29. Cloutier, S.; Larson, L.; Jambeck, J. Are Sustainable Cities "Happy" Cities? Associations Between Sustainable Development and Human Well-Being in Urban Areas of the United States. Environ. Dev. Sustain. 2014, 16, 633-647. [CrossRef]

30. Talmage, C.A. Making the Ordinary Extraordinary: A Fresh Look at Satisfaction in Communities. In $A$ New Research Agenda for Improvements in Quality of Life, Social Indicators Research Series; Maggino, F., Ed.; Springer: Cham, Switzerland; Dordrecht, The Netherlands, 2015; pp. 61-86. ISBN 978-3-319-15903-4.

31. Badham, M. Democratising Cultural Indicators: Developing A Shared Sense of Progress. In Making Culture Count; MacDowall, L., Badham, M., Blomkamp, E., Dunphy, K., Eds.; Palgrave Macmillan: London, UK, 2015; pp. 195-213. ISBN 978-1-349-56539-9.

32. Lee, S.J.; Kim, Y.; Phillips, R. (Eds.) Community Well-Being and Community Development: Conceptions and Applications; Springer: Cham, Switzerland, 2015; ISBN 978-3-319-12421-6.

33. United Nations. World Urbanization Prospects: The 2018 Revision. Available online: https: / / esa.un.org/ unpd/wup/Publications/Files/WUP2018-KeyFacts.pdf (accessed on 28 October 2018).

34. Wheeler, S.M. Planning for Sustainability: Creating Livable, Equitable and Ecological Communities; Routledge: London, UK, 2013; ISBN 9781136482014.

35. Luederitz, C.; Lang, D.J.; Von Wehrden, H. A systematic review of guiding principles for sustainable urban neighborhood development. Landsc. Urban Plan. 2013, 118, 40-52. [CrossRef]

36. Sharifi, A. A critical review of seven selected neighborhood sustainability assessment tools. Environ. Impact Assess. Rev. 2013, 38, 73-87. [CrossRef]

37. Ahmadi, F.; Toghyani, S. The Role of Urban Planning in Achieving Sustainable Urban Development. OIDA Int. J. Sustain. Dev. 2011, 2, 23-26.

38. Hagen, B.; Middel, A. What Should Sustainable Cities Look Like? Programs, Policies, and Initiatives. In Sustainability for the 21st Century: Pathways, Programs, and Policies, 2nd ed.; Hagen, B., Pijawka, K.D., Eds.; Kendall Hunt: Dubuque, IA, USA, 2018; pp. 53-86. ISBN 1524918105. 
39. Ahmed, K.G. Urban Social Sustainability: A Study of The Emirati Local Communities in Al Ain. J. Urban Int. Res. Placemaking Urban Sustain. 2012, 5, 4-66. [CrossRef]

40. Li, F.; Wang, R.; Paulussen, J.; Liu, X. Comprehensive Concept Planning of Urban Greening Based on Ecological Principles: A Case Study in Beijing, China. Landsc. Urban Plan. 2005, 72, 325-336. [CrossRef]

41. Webster, D.; Zhang, F.; Cai, J. China's Pursuit: Smart Sustainable Urban Environments. In Sustainability for the 21st Century: Pathways Programs and Policies, 2nd ed.; Pijawka, K.D., Hagen, B., Eds.; Kendall Hunt Publishing Company: Dubuque, IA, USA, 2017.

42. Joubert, L. Creative Communities: The Arts, Social Responsibility and Sustainable Planning and Development. In The Sustainable City III; Marchettini, N., Brebbia, C.A., Tiezzi, E., Wadhwa, L.C., Eds.; WIT Press: London, UK, 2004; pp. 473-482. ISBN 1-85312-720-5.

43. Jones, C.; Leishman, C.; MacDonald, C. Sustainable Urban Form and Residential Development Viability. Environ. Plan. A 2009, 41, 1667-1690. [CrossRef]

44. Hopwood, B.; Mellor, M.; O’Brien, G. Sustainable Development: Mapping Different Approaches. Sustain. Dev. 2005, 13, 38-52. [CrossRef]

45. Galster, G.; Quercia, R.; Cortes, A. Identifying Sustainable Neighborhoods: An Empirical Exploration of Threshold Effects. In The Sustainable City: Urban Regeneration and Sustainability; Brebbia, C.A., Ferrante, A., Rodriguez, M., Terra, B., Eds.; WIT Press: Southampton, UK, 2000; pp. 371-380. ISBN 1845645782.

46. Bramley, G.; Dempsey, N.; Power, S.; Brown, C.; Watkins, D. Social Sustainability and Urban Form: Evidence from Five British Cities. Environ. Plan. A 2009, 41, 2125-2142. [CrossRef]

47. Stren, R.; Polese, M. Understanding the New Sociocultural Dynamics of Cities: Comparative Urban Policy in A Global Context. In The Social Sustainability of Cities: Diversity and The Management of Change; Polese, M., Stren, R., Eds.; University of Toronto Press: Toronto, ON, Canada, 2000; pp. 3-38.

48. Littig, B.; Griessler, E. Social Sustainability: A Catchword Between Political Pragmatism and Social Theory. Int. J. Sustain. Dev. 2005, 8, 65-79. [CrossRef]

49. Department for Communities and Local Government. National Planning Policy Framework. Available online: https:/ / www.gov.uk/guidance/national-planning-policy-framework (accessed on 28 October 2018).

50. Woodcraft, S. Social Sustainability and New Communities: Moving from Concept to Practice in the UK. Procd. Soc. Behv. 2012, 68, 29-42. [CrossRef]

51. Winter, J.; Farthing, S. Coordinating Facility Provision and New Housing Development: Impacts on Car and Local Facility Use. In Evaluating Local Environmental Policy; Farthing, S.M., Ed.; Avebury: Aldershot, UK, 1997; pp. 159-179. ISBN 1859723217.

52. Aldous, T. Urban Villages: A Concept for Creating Mixed-Use Urban Developments on a Sustainable Scale; Urban Villages Group: London, UK, 1992; ISBN 0951902806.

53. Barton, H. The Neighbourhood as Ecosystem. In Sustainable Communities: The Potential for Eco-Neighbourhoods; Barton, H., Ed.; Routledge: London, UK, 2000; pp. 86-104. ISBN 9781317973317.

54. Burton, E. The Compact City: Just or Just Compact? A Preliminary Analysis. Urban Stud. 2000, 37, $1969-2001$. [CrossRef]

55. Ghahramanpuri, A.; Abdullah, A.S.; Sedaghatnia, S.; Lamit, H. Urban Social Sustainability Contributing Factors in Kuala Lumpur Streets. Procedia-Soc. Behav. Sci. 2015, 201, 368-376. [CrossRef]

56. Crowhurst Lennard, S.H.; von Ungern-Sternberg, S.; Lennard, H.L. (Eds.) Making Cities Livable: Wege zur Menschlichen Stadt; Gondolier Press: Carmel, CA, USA, 1997; ISBN 0935824073.

57. Drilling, M.; Schnur, O. (Eds.) Sustainable District Development: Positions, Practical Examples and Perspectives; VS Verlag: Wiesbaden, Germany, 2012; ISBN 978-3-531-94150-9.

58. Frey, W. Freiburg Green City: Approaches to Sustainable Urban Development; Herder: Freiburg, Germany, 2013; ISBN 978-3-451-30981-6.

59. Medearis, D.; Daseking, W. Freiburg, Germany: Germany's Eco-Capital. In Green Cities in Europe; Beatley, T., Ed.; Island Press: Washington, DC, USA, 2012; pp. 29-64. ISBN 978-1-59726-220-0.

60. Nössler, B.; de Witt, M. Wyhl: Kein Kernkraftwerk in Wyhl und Auch Sonst Nirgends: Betroffene Bürger berichten (Wyhl: No Nuclear Power Plant in Wyhl and Nowhere Else: Affected Citizens Report); Inform-Verlag: Freiburg, Germany, 1976; ISBN 3921472016.

61. Mössner, S. Urban Development in Freiburg, Germany-Sustainable and Neoliberal? J. Geogr. Soc. Berlin 2015, 146, 189-193. [CrossRef]

62. Dresel, T.; Environmental Protections Agency, Freiburg, Germany. Personal communication, July 2014. 
63. Rohracher, H.; Späth, P. The Interplay of Urban Energy Policy and Socio-Technical Transitions: The Eco-Cities of Graz and Freiburg in Retrospect. Urban Stud. 2014, 51, 1415-1431. [CrossRef]

64. Scheurer, J.; Newman, P. Vauban: A European Model Bridging the Green and Brown Agendas. Case Study Prepared for Revisiting Urban Planning: Global Report on Human Settlements 2009. Available online: https://www.researchgate.net/publication/228970605_Vauban_A_European_Model_Bridging_ the_Green_and_Brown_Agendas (accessed on 28 October 2018).

65. Field, S. Case Study: Vauban: Freiburg, Germany. ITDP Europe, 2017. Available online: https://www.itdp. org/wp-content/uploads/2014/07/26.-092211_ITDP_NED_Vauban.pdf (accessed on 28 October 2018).

66. GreenCity Freiberg. Approaches to Sustainability. Available online: https://www.freiburg.de/pb/site/ Freiburg/get/params_E-1494413984/640888/GC-E2018.pdf (accessed on 28 October 2018).

67. Talmage, C.A.; Lacher, R.G.; Pstross, M.; Knopf, R.C.; Burkhart, K.A. Captivating Lifelong Learners in the Third Age: Lessons Learned from A University-Based Institute. Adult Educ. Q. 2015, 65, 232-249. [CrossRef]

68. Field, A. Discovering Statistics Using SPSS, 2nd ed.; Sage: London, UK, 2005; ISBN 1446249182.

69. Hamiduddin, I.; Daseking, W. Community-Based Planning in Freiburg, Germany: The Case of Vauban. In Community Action and Planning; Gallent, N., Ciaffi, D., Eds.; Policy Press: Bristol, UK, 2014; ISBN 9781447315162.

70. Barlow, J.G.; Jackson, R.; Meikle, J. Homes to DIY for. The UK's Self-Build Housing Market in the Twenty-First Century; Joseph Rowntree Foundation: York, UK, 2001; ISBN 1-84263-039-3.

71. Roessler, A.; Rieselfeld Resident and president of BIV Rieselfeld e.V.; Schuster, A., Vauban Resident. Personal communication, July 2014.

72. Perkins, D.D.; Hughey, J.; Speer, P.W. Community psychology perspectives on social capital theory and community development practice. Community Dev. J. 2002, 33, 33-52. [CrossRef]

73. Talmage, C.A.; Peterson, C.B.; Knopf, R.C. Punk rock wisdom: An emancipative psychological social capital approach to community well-being. In Handbook of Community Well-Being Research; Phillips, R., Wong, C., Eds.; Springer: Dordrecht, The Netherlands, 2017; pp. 11-38. ISBN 978-94-024-0878-2.

74. Rossi, P.H.; Weber, E. The social benefits of homeownership: Empirical evidence from national surveys. Hous. Policy Debate 1996, 7, 1-35. [CrossRef]

75. Coulter, R.; Van Ham, M.; Feijten, P. A longitudinal analysis of moving desires, expectations and actual moving behaviour. Environ. Plan. A 2011, 43, 2742-2760. [CrossRef]

76. Chaskin, R.J.; Joseph, M.L. Relational expectations and emerging reality: The nature of social interaction in mixed-income developments. J. Urban Affairs 2011, 32, 209-237. [CrossRef] 